\title{
Preparation of Thermostable Poly(Ethylene Glycol) Using Thermal Treatment in Sealed System
}

\author{
Carmem D. Cardoso ${ }^{a}$, Majulaine Copetti ${ }^{b}$, Leticia Schwerz $^{b}$, Nádia Viaro $^{b}$ and Martha Adaime ${ }^{b^{*}}$ \\ ${ }^{a}$ Escola de Farmácia - Universidade Católica de Pelotas - RS, Brazil \\ ${ }^{\mathrm{b}}$ Departamento de Química - Universidade Federal de Santa Maria - \\ Campus Camobi - 97105-900 - Santa Maria - RS, Brazil
}

\begin{abstract}
O trabalho descreve um método rápido para a preparação de Carbowax 20M imobilizada sobre suporte, através do uso de tratamento térmico em forno convencional. O processo de extração com solventes remove a fase estacionária não imobilizada de poli(etileno glicol) (PEG) do suporte e a diferença de massa antes e após a extração fornece o percentual extraído e, consequentemente, o percentual total imobilizado. $\mathrm{O}$ tratamento térmico a $250{ }^{\circ} \mathrm{C}$ por 10 horas mostrou que a imobilização reduziu a atividade do material e aumentou o número de pratos $(\mathrm{N})$ e a resolução (Rs), enquanto o fator de retenção (k) reduziu. Desta forma, a separação na coluna com material tratado é mais rápida e mais eficiente.
\end{abstract}

A rapid method is described for preparation of support - bonded Carbowax 20M columns packing using a conventional furnace to heat the packing. Solvent extraction of the stationary phase removes the non-immobilized poly(ethylene glycol) (PEG) from the support and the difference between final and initial weight provides the total percent extracted and, consequently, the total percent immobilized. Treatment of the packing material at $250{ }^{\circ} \mathrm{C}$ for $10 \mathrm{~h}$. reveals that the immobilization reduces the material activity and increases the plates number $(\mathrm{N})$ and resolution $(\mathrm{Rs})$ while the retention factor $(\mathrm{k})$ is decreased. Thus, separations with this treated column are faster and display higher efficiency.

Keywords: thermal treatment, immobilization, Carbowax 20M, capillary gas chromatography

\section{Introduction}

Carbowax ${ }^{\circledR}$ PEG 20M is widely used in gas chromatography (GC) because of its unique selectivity, which allows resolution of polar compounds having similar boiling points. However, the ease of oxidation and low thermal stability of this stationary phase reduce its application in GC.

The development of bonded Carbowax capillary columns in recent years has increased, due to its high stability, extended column lifetime as well as the easy removal of residue materials from contaminated column. Immobilization of the stationary phase is generally achieved by bonding the polymer chain to the support. This immobilization process is initiated by free radicals which are produced by heat $1-5$, chemical initiators such as azocompounds ${ }^{6-8}$, peroxides ${ }^{9-13}$ or ozone ${ }^{14,15}$, and ionizing radiation such as electrons ${ }^{16}$, gamma radiation 17,18 and low-temperature plasmas ${ }^{19}$. All these methods have been successfully applied to produce immobilized nonpolar silicone phases within capillary columns. On the other hand, very little information exists on immobilization of supported stationary phases used in packed-column gas chromatography.

Support-bonded Carbowax 20M column packing has recently become available from several commercial sources.
The cost of these materials is high compared with that of conventional column packings, and variations in quality among batches and suppliers have been noticed.

In this article a rapid method is described for the preparation of support-bonded Carbowax 20M column packing. A conventional furnace was used to heat the packing which was sealed inside a glass ampoule.

\section{Experimental}

\section{Materials}

20\% Carbowax 20M (Merck) on Chromosorb W/AW (80-100 mesh, Merck) was prepared by evaporation ${ }^{20}$ of solvent. This material was placed in borosilicate glass ampoules which were sealed under $\mathrm{N}_{2}$ and heated at different temperatures $\left(200,250,300,350\right.$ and $\left.400{ }^{\circ} \mathrm{C}\right)$ for 5 and $10 \mathrm{~h}$.

\section{Column preparation}

The prepared phases were packed into identical stainless steel columns with the aid of a vibrator. The packing density was controlled by weight. 


\section{Equipment}

A Varian 3400 Gas Chromatograph with flame ionization detector was used with $1.5 \mathrm{~m}$ x $0.2 \mathrm{~cm}$ (i.d.) stainless steel columns placed to permit on-column injection. Visible spectra were obtained on a Perkin-Elmer model 116 spectrophotometer.

\section{Packing characterization}

Solvent extractions of immobilized and non-immobilized packing materials were carried out at reflux temperature for $5 \mathrm{~h}$. with each of three solvents (methanol, benzene and chloroform) using a modification of the method of Sanchez et al. 21 .

Methyl orange adsorption on the active surface, used to determine the relative difference between well-coated and noncoated particles, was carried out by a modification of the method of Shapiro and Kolthoff 22 . Known quantities of the packing materials were stirred in contact with $5 \%(\mathrm{v} / \mathrm{v})$ of methyl orange in acetic acid solution. After a fixed time the suspension was filtered and the absorbance of the methyl orange remaining in solution was measured at $505.6 \mathrm{~nm}$. The surface activity was determined from the difference in absorption between pure and filtered methyl orange solutions, after contact.

\section{Chromatography}

Two different polar mixtures (methyl octanoate/methyl hexanoate at $160^{\circ} \mathrm{C}$ and cyclohexanol/cyclohexanone at $160^{\circ} \mathrm{C}$ ) were used to evaluate the chromatographic parameters of the phases using a flow rate of $30 \mathrm{~mL} \mathrm{~min}^{-1}\left(\mathrm{~N}_{2}\right)$. The $\mathrm{t}_{\mathrm{M}}$ (Mobile Phase Retention Time) was determined with butane at three different temperatures $\left(120,140\right.$ and $\left.160^{\circ} \mathrm{C}\right)$.

To verify their thermal stability (bleeding) the columns were submitted to high temperatures $\left(250^{\circ} \mathrm{C}\right)$ and the background current was registered.

In the thermogravimetric simulation these packings were heated under $\mathrm{N}_{2}$ and weighted several times using a special ampoule adapted for Gas Chromatography.

\section{Results}

Solvent extraction of the stationary phase removes the non-immobilized poly(ethylene glycol) from the support and the final and initial weight difference provide the total percent extracted and, consequently, the total percent immobilized. Temperature of $400^{\circ} \mathrm{C}$ causes immobilization of a significant quantity of the phase (up to $80 \%$ ), but at $200{ }^{\circ} \mathrm{C}$ no significant immobilization is observed. However, at $400^{\circ} \mathrm{C}$ and $350^{\circ} \mathrm{C}$ treated packings underwent decomposition, appearing to be burned.
The relative difference between well-coated and noncoated particles was evaluated as shown in Table 1 . The chromatographic separations are shown in the Figures 1 and 2, comparing immobilized and non-immobilized columns.

Table 1. Difference in adsorption (DA*) between pure methyl orange solution and the filtered methyl orange solution after contact with different materials.

\begin{tabular}{lcc}
\hline Sample/Treated Material & Absorbance & DA* $^{*}$ \\
\hline Pure dye solution & 0.2079 & \\
Chromosorb W AW & 0.1764 & 0.0315 \\
Blank material & 0.1763 & 0.0316 \\
Material immobilized at $200^{\circ} \mathrm{C} / 5 \mathrm{~h}$ & 0.1586 & 0.0493 \\
Material immobilized at $200^{\circ} \mathrm{C} / 10 \mathrm{~h}$ & 0.1587 & 0.0492 \\
Material immobilized at $250^{\circ} \mathrm{C} / 5 \mathrm{~h}$ & 0.1862 & 0.0217 \\
Material immobilized at $250^{\circ} \mathrm{C} / 10 \mathrm{~h}$ & 0.1920 & 0.0159 \\
Material immobilized at $350^{\circ} \mathrm{C} / 5 \mathrm{~h}$ & 0.1872 & 0.0207 \\
Material immobilized at $350^{\circ} \mathrm{C} / 10 \mathrm{~h}$ & 0.1837 & 0.0242 \\
Material immobilized at $400^{\circ} \mathrm{C} / 5 \mathrm{~h}$ & 0.1624 & 0.0455 \\
Material immobilized at $400^{\circ} \mathrm{C} / 10 \mathrm{~h}$ & 0.1613 & 0.0466 \\
\hline
\end{tabular}
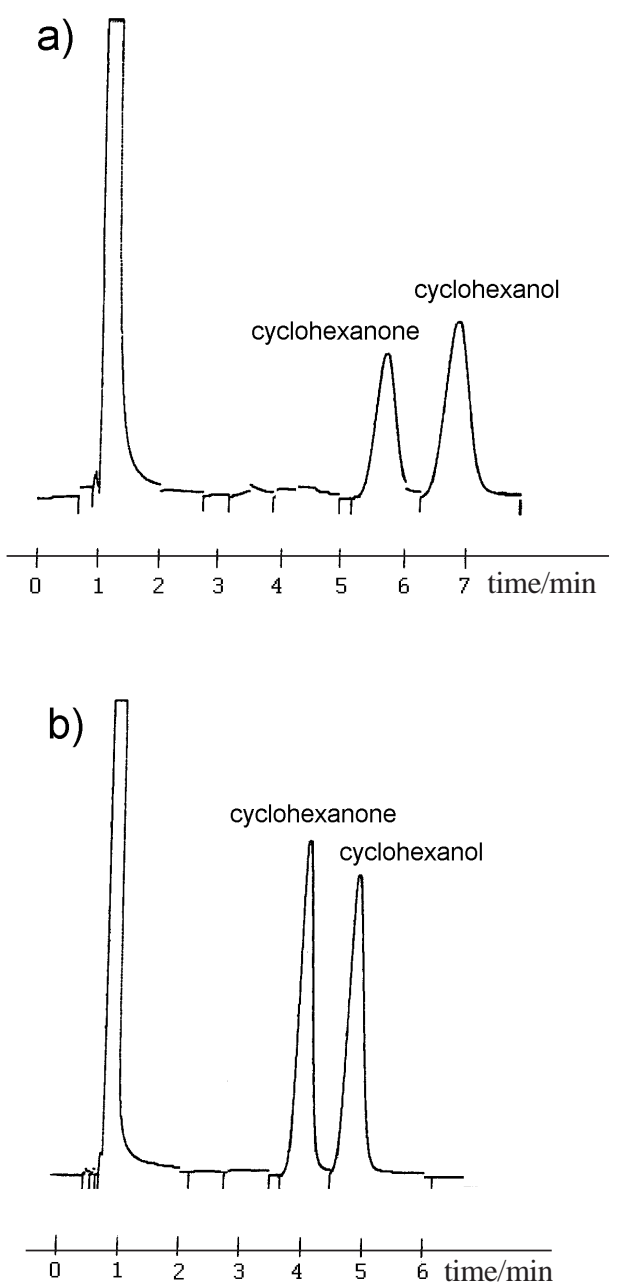

Figure 1. Separation of cyclohexanol and cyclohexanone in (a) nonimmobilized and (b) immobilized $\left(250^{\circ} \mathrm{C} / 10\right.$ h. $)$ columns. 
The effect of immobilization on thermal stability is shown by measurements of the background current, indicated in Figure 3.

Thermal stability is also determined by thermogravimetric simulation (Figure 4).
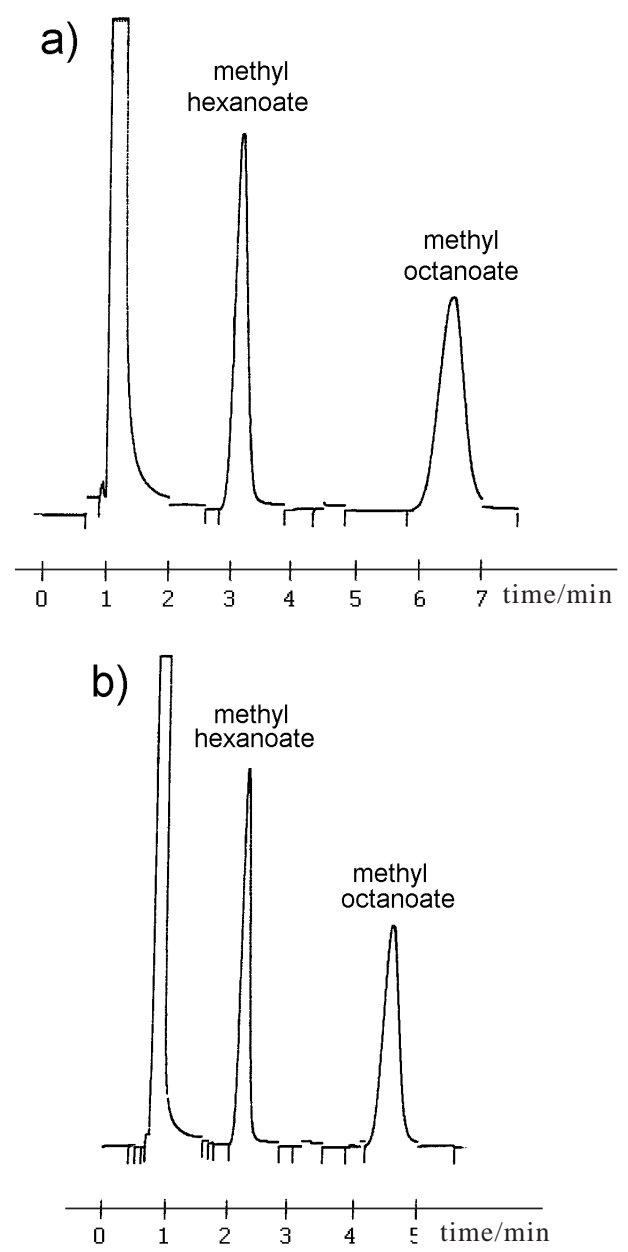

Figure 2. Separation methyl hexanoate and methyl octanoate in (a) non-immobilized and (b) immobilized $\left(250{ }^{\circ} \mathrm{C} / 10\right.$ hours) columns.

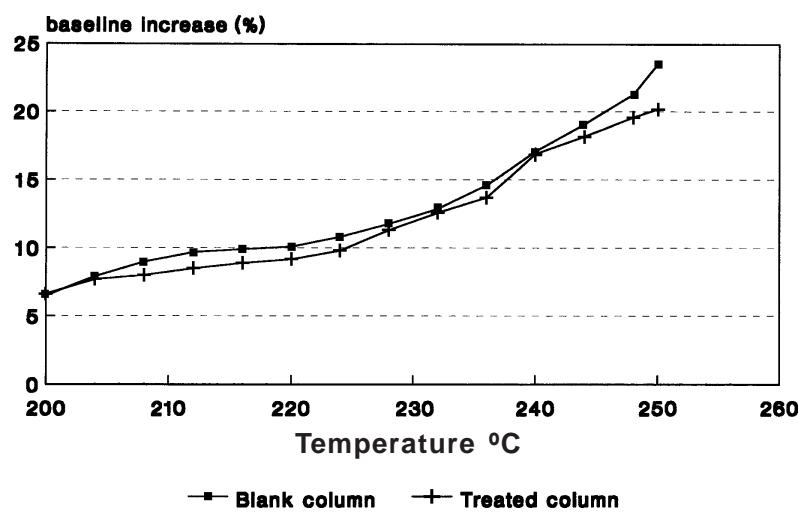

Figure 3. Effect of Carbowax 20M immobilization on background current.

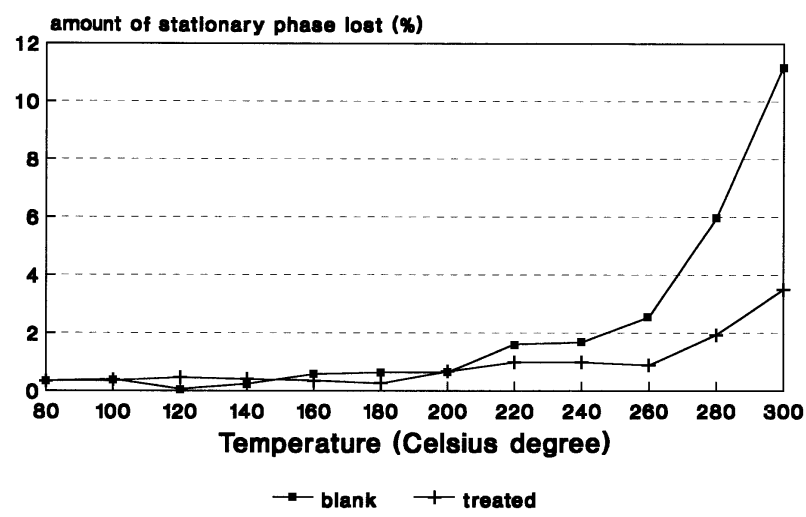

Figure 4. Percentage of the liquid stationary phase (Carbowax 20M) lost as a function of the temperature for blank and treated packings.

The necessary temperature to cause increase in the background current is higher for immobilized than for the nonimmobilized phase indicating an increase in stability with this treatment.

\section{Discussion}

Although treatment at $250{ }^{\circ} \mathrm{C}$ showed only $1.5 \%$ of immobilization, this material was chosen due to its better chromatographic performance.

The increased absorbance of the packing immobilized at $250^{\circ} \mathrm{C}$ for $10 \mathrm{~h}$, compared with the non-immobilized one reveals that immobilization reduces the packing activity.

The immobilized column possesses a greater plate number (N) and higher resolution (Rs) than the non-immobilized column, while the retention factor $(\mathrm{k})$ decreased after immobilization.

These results are similar to those obtained by Aue et al. ${ }^{1}$ who used temperature treatments of $260^{\circ} \mathrm{C}$ to $280^{\circ} \mathrm{C}$ for $12 \mathrm{~h}$. In that work the chromatographic behavior of polar compounds showed symmetric peaks with very short retention times.

This result is confirmed by thermogravimetric simulation where we observe that the immobilized packing lost 3.5 $\%$ of the stationary phase while the non-immobilized packing lost $11.0 \%$ of stationary phase at $300{ }^{\circ} \mathrm{C}$.

\section{Conclusion}

We conclude that the preparation of Carbowax 20M phase immobilized on Chromosorb W/AW is a simple method that uses a sealed system, minimizing the stationary phase loss. This procedure produces efficient columns with higher plate number and smaller retention factor than the non-immobilized columns. 


\section{References}

1. Aue, W.A.; Hasting, C. R.; Kapila, S. J. Chromatogr. 1973, 77, 299.

2. Lipsky, S. R.; McMurray, W. J. J. Chromatogr. 1982, 239, 61.

3. Petsev, N. D.; Pekov, G. I.;Alexandrova,M. D.; Dimitrov, C. Chromatographia 1985, 20, 228.

4. Sandra, P.; David, F.; McNair, H. M. Analysis 1992, 20, 117.

5. Lai, G.; Mühleck, U.; Nicholson, G. J.; Schmid, J.; Bayer, E. Chromatographia 1991, 32, 241.

6. Richter, B. E.; Kuei, J. C.; Park, N. J.; Crowley, S. J.; Bradshaw, J. S.; Lee, M. L. J. High Resol. Chromatogr. Chromatogr. Commun. 1983, 6, 371.

7. Janák, K.; Horká, M.; Tesarík, K. J. Chromatogr. 1989, 471, 237.

8. Horká, M.; Kahle, V.; Krejcí, M. J. Chromatogr. 1993, 637, 96.

9. Grob, K.; Grob, G. J. Chromatogr. 1981, 211, 243.

10. Wright, B. W.; Peaden, P. A.; Lee, M. L.; Seark, J. J. Chromatogr. 1982, 248, 17.

11. Blomberg, L.; Buijten, J.; Markides, K.;Wannman, T.
J. Chromatogr. 1982, 239, 51.

12. Ghijsen, R. T.; Nooitgedacht, F.; Poppe, H. Chromatographia 1986, 22, 201.

13. Cigánek, M.; Dressler, M.; Teplý, J. J. Chromatogr. 1991, 588, 225.

14. Grob, K.; Grob, G. J. Chromatogr. 1981, 213, 211.

15. Chuang, C. H.; Shanfield, H.; Zlatkis, A. Chromatographia 1987, 3, 169.

16. Markides, K.; Blomberg, L.; Buijten, J.; Wannman, T. J. Chromatogr. 1983, 267, 29.

17. Hubball, J. A.; DiMauro, P. R.; Barry, F.; Lyons, E.A.; George, W.A. J. Chromatogr. Sci. 1984, 22, 185.

18. Basso, M.A.; dos Santos, M. J. T. F.; Collins, K. E.; Collins, C. H. J. High Resol.Chromatogr. Chromatogr. Commun. 1989, 7, 500.

19. Springston, S. R.; Dezaro, D. A. J. Chromatogr. 1989, $473,79$.

20. Supina, W. R. The Packed Column in Gas Chromatography; Supelco Inc.; Bellefonte, PA, 1974.

21. Sanchez, E. F.; Dominguez, J. A.; Munõz, J. A. G.; Molera, M. J. J. Chromatogr. 1984, 299, 151.

22. Shapiro, J.; Kolthoff, I. M. J. Am. Chem. Soc. 1950, 72,776 . 